\title{
STRATEGI DAKWAH RASULULLAH DI MADINAH
}

\author{
MAHMUDDIN \\ Fakultas Dakwah dan Komunikasi \\ Universitas Islam Negeri (UIN) Alauddin Makassar \\ Email : mahmuddin.dakwah@uin-alauddin.ac.id
}

\begin{abstract}
:
The main problem in this research is how is the da'wah Rasulullah in Medina. The subject matter next on intro research viz: how to preach strategy steps Rasulullah in Medina? The object of this research is da'wah strategi Rasulullah practiced in Medina. The method used is use the documentation method and analysis of historical texts. The result showed that Rasulullah saw. In carrying out the da'wah has used tactics and rate-steps da'wah strategy in Medina, starting from Mecca to the missionary journey in Medina. Implementation of the steps of the prophet's propaganda strategy in the form of missionary planning, the strategy of organizing da'wah, implementation da'wah strategy and da'wah control and evaluasion strategy, all of them have been implemented in a strict and structured manner.
\end{abstract}

Keywords : strategy, da’wah, Rasulullah saw, Medina.

\section{PENDAHULUAN}

Rasulullah saw. adalah seorang pemimpin dunia yang paling berpengaruh dan diakui oleh kawan dan lawan. ${ }^{1}$ Pengakuan tersebut bukan tidak berdasar, tetapi kenyataan menunjukkan bahwa ajaran yang dibawanya memiliki pengaruh yang sangat siginifikan di seluruh dunia dan memiliki pengikut yang tidak pernah berkurang bahkan semakin bertambah di suatu negara, kalaupun ia ditekan di suatu daerah, maka ia bangkit di daerah lain dan perkembangan semakin pesat. Makkah dan Madinah sebagai pusat ibadah menunjukkan bahwa sepanjang tahun tidak pernah sunyi dari umat Islam untuk beribadah dan Ka'bah sebagai pusat galaksi terus berputar dikelilingi umat Islam setiap detiknya. Semuanya itu merupakan manifestasi dari ajaran Rasulullah saw. Kesemuanya itu bisa berjalan berkat strategi dakwah yang telah diterapkan oleh Rasulullah saw. telah berjalan dengan baik.

Perjalanan dakwah Rasulullah saw. yang membawa syari'at Islam dan yang dijadikannya sebagai landasan operasional dakwah dan sebagai pikajakan oleh umat manusia dewasa ini, semua ini berawal dari pejalanan dakwah Nabi Muhammad saw. Risalah yang beliau bawakan adalah dari ajaran Ilahi yang

1 Michael H. Hart, The 100, A Ranking of the Most Infleluential Person in History". Diterjemahkan oleh Mahbub Djunaedi dengan Judul 100 Tokoh Paling Berpengaruh Sepanjang Sejarah, Diva Press, 1978. 
merupakan lanjutan dari risalah sebelumnya. Risalah tersebut diperuntukkan kepada seluruh umat manusia. ${ }^{2}$

Agama dakwah adalah agama yang mengandung ajaran kebenaran yang memerlukan upaya menyebarluaskannya kepada umat manusia sebagai suatu kebenaran dan mengajak orang lain untuk mempercayainya, semangat memperjuangkan kebenaran itu berjalan terus pernah dan tidak padam dalam jiwa umatnya. ${ }^{3}$ Kegiatan dakwah tersebut diperhadapkan pada akulturasi budaya dan kondisi masyarakat yang telah memeluk agama Islam dan bahkan berbagai perubahan sebagai akibat banyaknya ummat Islam yang hijrah ke Madinah, yang sekaligus merubah sistem ekonomi, sosial budaya dan bahkan status sosial.

Problematika dakwah tersebut dituntut sumber daya subyek dakwah yang berkualitas dan berkemampuan tinggi, terutama pada penentuan langkah proses dakwah yang efektif dan efisien. Pada diri pelaksana dakwah (terutama Nabi dan sahabat-sahabatnya sebagai prajurit risalah) menjadi tumpuan harapan masa depan Islam dalam menjalankan roda pelaksanaan dakwah menuju tercapainya tujuan dakwah.

Manajemen mempunyai kecenderungan mengorganisir dan bekerja bersama-sama dalam hubungan yang saling bergantung merupakan hal yang inherent ${ }^{4}$ oleh orang modern dewasa ini boleh dikatakan tidak ada suatu usaha kerja sama manusia untuk mencapai suatu tujuan tertentu yang tidak mempergunakan manajemen. Dakwah yang mempunyai area yang sangat luas, tidak dapat berjalan secara efisien tanpa diikuti dengan manajemen.

Untuk kepentingan tersebut, maka penggunaan prinsip-prinsip manajemen mutlak diperlukan, terutama dalam mencapai suatu cita-cita yang sangat besar. Hal tersebut tercermin pada upaya Rasul dalam mengembang amanat Allah di Madinah. Al-Madinah adalah nama yang paling masyhur dan terkenal hingga saat ini. Nama ini diberikan oleh Nabi Muhammad saw. sendiri, sebagaimana termuat dalam berbagai hadis. ${ }^{5}$

Pada wacana seperti tersebut di atas, rujukan utamanya sebagai tempat berpijak adalah tinjauan historis kehidupan Nabi di Madinah sebagai objek kajian,

${ }^{2}$ Hamka Haq, Filsafat Ushul Fiqh (Ujungpandang: Yayasan Al-Ahkam, 1998), h.1.

${ }^{3}$ Syaikh Abdurrahman Abdul Khaliq, Fus-lun min Nasiyasati Syar'iyati fi Dakwah Ilal Allah, diterjemahkan oleh Marsuni Sosaky dan Mustahab Hasbullah, dengan judul Metode dan Strategi Dakwah Islam (Jakarta: Pustaka al-Kausar, 1996), h. 75-76.

${ }^{4}$ Fremont E. Kast dan James E. Rosenzwing, Organizing and Management. Diterjemahkan oleh A. Hasjmi Ali dengan judul Organisasi dan Manajemen Jilid I (Jakarta: Bumi Aksara, 1995), h. 3 .

${ }^{5}$ Khalid Ibrahim Malla Khathir, Fadhail al-Madinah al-Munawwarah, Jilid I (Madinah: Maktabah Dar al-Turats, 1993), h. 157, Kata tersebut diabadikan dalam Q.S. al-Munaafiqun ayat 8. 
dan hal terpenting pula adalah mengkaji secara mendalam tentang teori-teori manajemen yang digunakan Nabi, sehingga mampu membentuk suatu masyarakat ideal di Madinah.

\section{PEMBAHASAN}

\section{Tinjauan Strategi Dakwah}

Istilah strategi dakwah banyak dijumpai rumusan dan tujuannya, rumusan tersebut dapat dilihat dalam berbagai sumber. Hasan Basri telah membatasi ruang lingkupnya dengan menonjolkan strategi dakwah yang dilakukan oleh Rasulullah di Madinah dan menjadikannya sebagai respon terhadap objek dakwah, aktivitas dakwah yang dilakukannya melalui penerapan Islam secara praktis di seluruh negeri. ${ }^{6}$

Strategi dakwah yang dikembangkan Rasulullah di Madinah adalah beliau tidak perlu menunggu serangan yang dilakukan oleh musuh, akan tetapi Rasulullah saw. melakukan jihad ketika dakwah yang dilakukannya mendapat perlakuan yang mengarah pada kegiatan menghalangi dakwahnya. Langkah konkrit yang dilakukan oleh Rasulullah setelah tiba di Madinah adalah langsung membentuk tim ekspedisi sebagai bentuk organisasi militer yang reguler. Inilah fenomena strategi dakwah yang harus dicermati aktivis dakwah kontemporer. ${ }^{7}$

Pandangan lain sebagai mana yang dilakukan oleh Walisongo mengemukakan bahwa strategi dakwah adalah mengajak manusia ke jalan Allah dengan memanfaatkan segala sumber daya yang dimiliki. ${ }^{8}$ Beberapa strategi Walisongo dalam pelaksanaan dakwah yaitu pembagian wilayah dakwah, sistem dakwah dilakukan dengan pengenalan ajaran Islam melalui pendekatan persuasif yang berorientasi pada penanaman aqidah Islam yang disesuaikan dengan situasi dan kondisi yang ada, melakukan perang ideologi untuk memberantas etos dan nilai-nilai dogmatis yang bertentangan dengan aqidah Islam, dimana para ulama harus menciptakan mitos dan nilai-nilai tandingan baru yang sesuai dengan Islam, melakukan pendekatan terhadap para tokoh yang dianggap mempunyai pengaruh di suatu tempat dan berusaha menghindari konflik, berusaha menguasai kebutuhan-kebutuhan pokok yang sangat dibutuhkan oleh masyarakat, baik kebutuhan yang bersifat materil maupun spiritual. ${ }^{9}$

\footnotetext{
${ }^{6}$ Hasan Basri. (2015). Manajemen Dakwah Nabi saw di Madinah. Al-Munzir, 8 (2), 179-196.

${ }^{7}$ Hasan Basri. (2015). Manajemen Dakwah Nabi saw di Madinah. Al-Munzir, 8 (2), 179-196.

${ }^{8}$ Hatmansyah, RS, S. (2009). Strategi Dan Etika Dakwah Rasulullah Saw. Ilmu Dakwah.

${ }^{9}$ Hatmansyah, Strategi dan Metode Dakwah Walisongo. Al-Hiwar : Jurnal Ilmu dan Teknik Dakwah, 3(5). https://doi.org/10.18592/al-hiwar.v3i5.1193
} 
Dakwah harus dikemas sedemikian rupa agar diterima dan dipahami oleh masyarakat sebagai mad'unya. Penggunaan strategi atau cara yang benar adalah tolok ukur keberhasilan dari dakwah itu sendiri. Tetapi jika strategi yang digunakan tidak tepat, akan mengarah pada hal yang tidak terduga. ${ }^{10}$

Strategi dakwah konvensional adalah terhadap ruang dan waktu. Karena itu dakwah diera teknologi informasi ini memiliki tantangan yang cukup besar di masyarakat. Sementara itu media online sudah menjadi keperluan sehari-hari masyarakat moden. Semua kalangan kini boleh mengakses media online dengan sangat mudah. Namun sangat disayangkan media ini lebih cenderung digunakan untuk mendapatkan maklumat dan hiburan saja, bahkan tidak jarang yang menyalahgunakan. Tanpa strategi yang tepat, dakwah melalui media online tidak akan berkesan dan berjaya. Hasil penulisan ini dapat dijadikan panduan asas oleh golongan pendakwah baik individual maupun institusi serta masyarakat Islam keseluruhan yang ingin melakukan dakwah melalui media online. ${ }^{11}$

Pengajian Yasinan merupakan salah satu amalan NU yang menjadi strategi di dalam mengembangkan dan menyebarkan agama. Keberadaan Pengajian Yasinan dapat ditemukan di berbagai daerah, terutama di pedesaan atau perkampungan yang masyarakatnya dari kalangan NU. Namun demikian pengaruh modernisasi telah mengakibatkan perubahan dalam masyarakat. ${ }^{12}$

Kemunculan dakwah Salafi di Indonesia berawal dari Dewan Dakwah Islam Indonesia (DDII) dan Lembaga Ilmu Pengetahuan Islam dan Bahasa Arab (LIPIA), yang memperkenalkan manhaj salâf as-sâlih kepada umat Islam Indonesia. Mereka didukung oleh lembaga-lembaga donor dari Timur Tengah berupa pendidikan gratis di Timur Tengah serta dana untuk mendirikan lembagalembaga untuk menunjang eksistensi dakwah Salafi, seperti pendirian yayasan, sekolah, rumah sakit, pondok pesantren, dan lembaga kursus bahasa Arab. ${ }^{13}$

Pondok Pesantren "Istighfar" merupakan satu-satunya pondok pesantren khusus mantan preman di Kota Semarang. Dalam pendirian Pondok Pesantren tersebut, para pengasuh mempunyai cita-cita dan komitmen yang sangat tinggi untuk memberikan pembinaan kepada para santri agar memiliki komitmen yang

${ }^{10}$ Syamsudin RS. (2009). Strategi Dan Etika Dakwah Rasulullah Saw. Ilmu Dakwah.

11 Hatmansyah, Strategi dan Metode Dakwah Walisongo. Al-Hiwar : Jurnal Ilmu dan Teknik Dakwah, 3(5). https://doi.org/10.18592/al-hiwar.v3i5.1193

12 Hayat (Universitas Islam Malang). (2014). Strategi Dakwah NU Dalam Membangun Mental Dan Karakter Masyarakat Walisongo. Jurnal Walisongo.

${ }^{13}$ Syamsuddin RS. (2009). Strategi Dan Etika Dakwah Rasulullah Saw. Ilmu Dakwah. 
kuat dalam meninggalkan tindak sosiopatic. Dalam melaksanakan tugas dakwahnya, pengasuh menggunakan pendekatan psikoterapi religius yang secara kontinu dilaksanakan di Pondok Pesantren tersebut. Di antara psikoterapi tersebut antara lain; psikoterapi melalui taubat, melalui keimanan, melalui amalan ibadah dan juga mengistikomahkan berzikir, berdoa dan mambaca al-Qur'an. ${ }^{14}$

\section{Rasulullah Sebagai Manajer Dakwah}

Kepemimpinan Rasulullah Muhammad saw. ${ }^{15}$ bila dibandingkan dengan kepemimpinan seorang manusia dewasa ini betapapun keadaanya, tentu tidak akan sebanding. Gelar Rasulullah saw. (utusan) Allah swt. tidak dapat dipersamakan dengan gelar apapun. ${ }^{16}$ Oleh karena itu, Rasulullah sebagai manajer sangat menarik untuk diteliti. Nabi Muhammad sebagai manajer, hidup dan tumbuh di tengah-tengah lingkungan yang bobrok dan rusak. ${ }^{17}$ Dengan bekal kepemimpinan manajerialnya, ia mampu menyingkirkan semua bentuk kebobrokan dan kerusakan.

Rahasia keberhasilan beliau adalah tidak terlepas dan sesuai dengan berbagai teori kepemimpinan yang berkembang dewasa ini. Abi Sujak menyebutkan bahwa penguasaan terhadap teori-teori kepemimpinan, manajer akan dapat menentukan gaya kepemimpinannya secara tepat sesuai tuntutan situasi dan kondisi bawahannya. ${ }^{18}$

Kunci sukses sebagai bukti keberhasilan kepemimpinan manajerialnya adalah sebagai berikut:

\section{Akhlak Nabi yang terpuji tanpa cela}

Muhammad sebelum diangkaat sebagai Rasul, terkenal lemah lembut namun penuh vitalitas, berakhlak mulia, jaujur dan tidak mementingkan diri sendiri. ${ }^{19}$ Beliau adalah manusia teladan diantara hamba Allah lainnya. Pengakuan tersebut selain dari manusia juga dari Allah swt. Dalam Alquran dan hadis Nabi

14 Dedy Susanto. (2013). Psikoterapi Religius Sebagai Strategi Dakwah Dalam Menanggulangi Tindak Sosiopatic (Studi di Pondok Pesantren Istighfar Semarang). Konseling Religi: Jurnal Bimbingan Konseling Islam.

${ }^{15}$ M. Fu'ad Hashem, Sirah Muhammad Rasulullah: Suatu Penafsiran Baru (Bandung: Mizan, 1989), h. 78-79. Simak pula Muhammad Athiliyahal-Abrasyiy, Adhamatur Rasul diterjemahkan oleh Muhammad Tohir dan Abulailah dengan judul Keagungan Muhammad Rasulullah saw (Bandung: Dunia Pustaka Jaya, 1985), h. 40.

${ }^{16}$ Abdurrahman al-Bagdadiy, Dakwah Islam dan Masa Depan Umat (Bangil: al-Izzah, 1997), h. 13.

${ }^{17}$ Husayn Ahmad Amin, al-Mi'ah al-Azam fi tarikh al-Islam (Bandung: Remaja Rosdakarya, 1999), h. 3.

${ }^{18}$ Abi Sujak, Kepemimpinan Manajer: Eksistensi dalam Perilaku Organisasi (Jakarta: Rajawali, 1990, h. 2.

${ }^{19}$ Nourouzzaman Shiddiq, Jeram-jeram Peradaban Muslim (Yogyakarta: Pustaka Pelajar, 1996), h. 102-108. 
tidak ada yang mencela akhlak beliau, bahkan hanya memujinya dengan pujian yang tinggi. Memperhatikan akhlak Nabi sebagai seorang pemimpin atau manajer, menjadi salah satu kunci keberhasilannya dalam menjalankan misinya, sehingga baik kawan maupun lawan mengaguminya.

2. Karakter yang tahan uji, tangguh, ulet, sederhana dan bersemangat baja

Muhammad lahir dalam keadaan yatim dan dalam usia enam tahun diapun menjadi yatim piatu, dalam keadaaan demikian beliau diasuh oleh kakeknya, diusianya yang kedelapan kakeknyapun wafat dan dipelihara oleh pamannya, dan dalam usia kanak-kanak beliau mengembala kambing dan ikut berdagang bersama pamannya. ${ }^{20}$ Dengan latar belakang kehidupan yang serba sederhana dengan liku kehidupan yang serba menantang, membuat dirinya semakin tangguh dan ulet di dalam menghadapi hidup dan kehidupannya.

\section{Sistem dakwah Nabi dengan metode hikmah}

Nabi di dalam menyerukan dakwahnya tidak pernah mengandung unsur paksaan, seperti talah diketahui dalam sejarah bahwa kota Mekah adalah pusat peribadatan bangsa Arab. Di sanalah terdapat Ka'bah sebagai tempat peribadatan mereka dalam bentuk kemusyrikan yang menjadi tradisi masyarakat. Dalam keadaan seperti itu, manusia yang satu-satunya dianggap mampu mengubahnya adalah Muhammad, karena beliaulah yang mendapat hikmah untuk memberi peringatan kepada kaumnya secara hikmah. Rasulullah melaluinya dengan jalan hikmah dalam upaya memperbaiki kondisi masyarakat Quraisy. Di dalam menjalankan dakwahnya dimulai secara sembunyi-sembunyi, lalu kemudian terang-terangan, itupun dilakukan pada kelompok-kelompok orang yang diperkirakan tidak akan mencelakakan dirinya dan agamanya, kesemua itu dilakukan dengan penuh hikmah. Oleh karena itu, dengan metode hikmah, ${ }^{21}$ maka seorang manajer akan mendapatkan kepercayaan penuh dari orang yang dipimpinnya.

\section{Tujuan perjuangannya jelas}

Dalam prinsip-prinsip manajemen dakwah disebutkan bahwa langkah awal dalam berdakwah adalah memperjelas sasaran yang ingin dicapai. ${ }^{22}$ Demikian pula Rasulullah sebagai manajer, beliau juga di dalam melaksanakan dakwahnya senantiasa memperjelas tujuan perjuangannya.

${ }^{20}$ Muhammad Athiliyahal-Abrasyiy, Adhamatur Rasul diterjemahkan oleh Muhammad Tohir dan Abulailah dengan judul Keagungan Muhammad Rasulullah saw (Bandung: Dunia Pustaka Jaya, 1985), h. 40-54.

${ }^{21}$ Sa'id bin Ali al-Qaththani, al-Hikmatu fi al-Dakwah ila Allah Ta'ala diterjemahkan oleh Masykur Hakim dan Ubaidillah dengan judul Dakwah Islam Dakwah Bijak (Jakarta: Gema Insani Press, 1994, h. 22-23.

${ }^{22}$ Adi Sasono, et all., Solusi Islam atas Problematika Umat (Ekonomi, Pendidikan dan Dakwah), (Jakarta: Gema Insani Press, 1998), h. 184. 


\section{Prinsip kebersamaan}

Karya pertama Nabi Muhammad setelah tibanya di Madinah adalah mendirikan masjid sebagai landasan yang kuat bagi kehidupan Islam. Masjid sebagai tempat ibadah dan berkumpulnya kaum muslimin, beliau dirikan dengan kerjasama yang baik. Beliau sendiri turut bekerja dengan tangannya sendiri. ${ }^{23}$ Masjid yang pertama dibangun adalah masjid Quba, beliau ikut menyingsingkan baju dan kaki jubanya untuk mengangkut tanah liat yang akan dijadikan dinding masjid. Dari berbagai peperangan yang terjadi semasa hidup beliau, hanya dua kali beliau tidak ikut perang yaitu perang Mu'tah dan perang Tabuk. ${ }^{24}$ Oleh karena itu, Rasulullah dalam menjalankan kepemimpinannya senantiasa memegang prinsip kebersamaan sebagai salah satu kunci kesuksesan.

\section{Prinsip persamaan}

Nabi dalam bergaul bersikap sama terhadap semua orang. Tutur sapanya, lemah lembutnya, senyum manisnya tidak berbeda antara satu dengan yang lain, antara si kaya dan si miskin, antara yang lemah dan yang kuat, antara musuh dan sahabat. ${ }^{25}$ Dalam catatan sejarah, tidak pernah ditemukan adanya sikap yang melebihkan antara satu dengan yang lain secara sengaja.

Prinsip persamaan yang dicanankan dalam Piagam Madinah tersebut meliputi persamaan hak akan hidup, hak keamanan jiwa, hak perlindungan baik laki-laki maupun perempuan dan baik golongan Islam maupun non Islam. ${ }^{26}$ Prinsip persamaan tersebut menunjukkan bahwa beliau adalah seorang manajer atau pemimpin yang padat dengan kebajikan.

\section{Mendahulukan kepentingan dan keselamatan pengikutnya}

Rasulullah di dalam membela kepentingan dan keselamatan umatnya dari sikap permusuhan dan siksaan orang-orang Quraisy jahiliah, beliau memerintahkan sebagian kaum muslimin untuk berhijrah ke Abessyniah (Habsyah) yang pertama dan kedua, ${ }^{27}$ Rasulullah bersama sahabatnya yang lain tetap tinggal di Makkah. Dengan sikap mendahulukan kepentingan dan

${ }^{23}$ Tim Penyusun Teks Book Sejarah Kebudayaan Islam Dirjen Bimbingan Islam, Sejarah dan Kebudayaan Islam, Jilid I (Ujungpandang: Proyek Pembinaan Perguruan Tinggi Agama IAIN Alauddin, 1981-1982), h. 34.

${ }^{24}$ Nourouzzaman Shiddiq, Jeram-jeram Peradaban Muslim (Yogyakarta: Pustaka Pelajar, 1996), h. 104.

${ }^{25}$ Nourouzzaman Shiddiq, Jeram-jeram Peradaban Muslim, h. 104.

26 J. Suyuthi Pulungan, Prinsip-prinsip Pemerintah dalam Piagam Madinah: Ditinjau dari Pandangan Alquran (Jakarta: Raja Grafindo Persada, 1996), h. 149-152.

${ }^{27}$ Thomas W. Arnold, The Preaching of Islam diterjemahkan oleh A. Nawawi Rambe dengan judul Sejarah Dakwah Islam (Jakarta: Widjaya, 1981), h. 14. Lihat juga Madjid Ali Khan, Muhammad the Final Massenger diterjemahkan oleh Fathul Umam dengan judul Muhammad saw. Rasul Terakhir (Bandung: Pustaka, 1985), h.70. Sedangkan Ibn Hisyam dan Phillip K.Hitti, The Arabs a Short History diterjemahkan oleh Ushuluddin Hutagalung dan ODP Sihombing dengan judul Dunia Arab Sejarah Singkat (Bandung: Sumur, t.th.), h. 36. 
keselamatan umatnya, membuat beliau semakin dicintai dan imannya semakin mantap, sebagai akibat adanya perhatian penuh dari pimpinan mereka sebagai pemimpin tertinggi.

8. Memberikan kebebasan berkreasi, berpendapat dan pendelegasian wewenang

Salah satu kunci keberhasilan beliau di dalam menjalankan fungsi kepemimpinan manajerialnya, adalah dengan memberikan kebebasan berkreasi dan berpendapat kepada sahabat yang diangkat menduduki satu jabatan. Hal tersebut tercermin dalam perbincangan Nabi dengan Mu'az bin Jabal ketika menerima jabatan sebagai gubernur di Yaman. ${ }^{28}$

Kematangan berpikir Mu'az tersebut adalah sebab adanya kebebasan berpendapat dan kewenagan yang diberikan kepadanya. Hal ini menjadi cermin bagi setiap pemimpin dalam rangka meraih sukses yang lebih besar.

\section{Tipe kepemimpinan kharismatis dan demokratis}

Secara harfiah, kepemimpinan kharismatik berarti penumpahan ampun. Secara maknawi mengandung arti kepatuhan dan kesetiaan atas dasar kepercayaannya kepada sang pemimpin. ${ }^{29}$

Rasulullah saw. dinilai oleh Hart sebagai pemimpin kharismatik dunia yang tiada tandingannya. Dikatakan juga bahwa di antara seratus tokoh yang berpengaruh di dunia, Muhammad adalah tokoh yang pertama, sedang Muhammad berasal dari keluarga yang sederhana, menyebarkan salah satu agama besar dunia yaitu agama Islam. ${ }^{30}$ Kepemimpinan Rasul juga bertipe demokratis, beliau selalu bermusyawarah dalam hal-hal mengatur hubungan antara manusia (muamalah) atau yang bersifat duniawi dan tidak ada ketentuan langsung dari Allah swt. ${ }^{31}$

Dari Sembilan kunci keberhasilan Nabi Muhammad saw. dalam menjalankan tugas kepemimpinannya telah meraih sukses, namun tidaklah berarti beliau mulus dari segala tantangan dan rintangan serta cobaan yang dipikulnya. Setelah selesai sati babak (di Makkah) sebagai satu dasawarsa penghinaan demi penghinaan. Disusulnya oleh satu keberhasilan dasawarsa keberhasilan demi

${ }^{28} \mathrm{Abu}$ 'Abdullah Ahmad bin Hanbal, Musnad Ahmad bin Hanbal, Jilid V (Beirut: alMaktab al-Islamy, 1978), h. 230, 236 dan 242. Lihat juga Imam Hafidz Abi Ali Muhammad bin Abdul Rahman bin Abd. Rahim al-Mabari al-Kufra, Tuhfatu al-Ahwaz bi Syarhi Jami' alTurmuzy, Jilid IV (Dar al-Fikr, 1979), h. 556-557. h. $12-13$.

${ }^{29}$ Onong Uchjana Effendi, Kepemimpinan dan Komunikasi (Bandung: Mandar Maju, 1992),

${ }^{30}$ Michael H. Hart, Seratus Tokoh yang Paling Berpengaruh dalam Sejarah (Jakarta: Pustaka Jaya, 1983), h. 27.

${ }^{31}$ Nourouzzaman Shiddiq, Jeram-jeram Peradaban Muslim, h. 106. 
keberhasilan di Madinah. ${ }^{32}$

\section{Strategi Perencanaan Dakwah Rasulullah}

Setelah Rasulullah saw. menjalankan tugas risalahnya di Mekkah, maka rencana selanjutnya adalah melirik kota Yastrib sebagai langkah dakwah selanjutnya. Yastrib adalah daerah sasaran dakwah Nabi yang dianggap cocok untuk mengembankan dakwah Islam. Hal itu didasari atas pertimbangan bahwa masyarakat Yastrib adalah masyarakat yang pluralis dan multi etnis, suku dan agama. Suku Aus dan Khazraj yang selalu bentrok lantaran tidak ada pemimpin yang dapat mempersatukan mereka, sedangkan agama Yahudi yang merka anut adalah agama samawi yang telah mengetahui akan datangnya seorang Nabi. ${ }^{33}$

Rencana Rasulullah yang matang terhadap kota Yastrib diawali dengan mengintai orang-orang Yastrib yang datang mengunjungi Mekkah untuk melaksanakan haji. Pada bulan Rajab tahun kesepuluh kenabian. ${ }^{34}$ Terdapat enam orang dari suku Aus dan Khazraj mengunjungi Mekkah. Nabi mendekati mereka dan menyampaikan ajaran Islam kepadanya di suatu tempat yang bernama 'Aqabah. ${ }^{35}$ Pada pertemuan itu, mereka tidak sedikitpun ragu atas penuturan Nabi itu dan semuanya memeluk agama Islam.

Selangkah demi selangkah dari rangkaian rencana Rasulullah memperlihatkan tanda-tanda keberhasilan sehingga tahun berikutnya 12 orang laki-laki Yastrib datang untuk memeluk dan mengucapkan ikrar di 'Aqabah pertama. $^{36}$

Adapun isi perjanjian 'Aqabah pertama adalah, "Kami tidak akan menyekutukan sesuatu dengan Allah, tidak akan mencuri tidak pula berzina, kami tidak akan membunuh anak-anak kami, dan hindari fitnah dalam segala bentuknya. Selalu taat kepada Nabi untuk melaksanakan segala sesuatu yang haq dan selalu beriman kepadanya, baik dalam gembira maupun sengsara." 37

Untuk menindaklanjuti perjanjian 'Aqabah pertama di atas, maka Rasulullah mengutus muballig yaitu Mus'ab bin Umair ke Yastrib untuk

${ }^{32}$ William E. Phipps, Muhammad and Jesus: A Comparison of The Prophets and Their Techings, diterjemahkan oleh Ilyas Hasan dengan judul Muhammad dan Isa: Sebuah Telaah Kritis atas Risalah dan Tokohnya (Bandung: Mizan, 1998), h. 79.

${ }^{33}$ Majid Ali Khan, Muhammad The Final Massenger diterjemahkan oleh Fathul Umam dengan judul Muhammad saw. Rasul Terakhir, h. 80.

${ }^{34}$ Syibli Nu'mani, Siratu Nabi, Jilid I, h. 262 dalam ibid.

${ }^{35}$ Abi Muhammad Abdul Malik bin Hisyam, Sirah al-Nabawiy, Jilid II (Beirut: Dar al-Fikr, t.th.), h. 39

${ }^{36}$ Abi Muhammad Abdul Malik bin Hisyam, Sirah al-Nabawiy, h. 431.

${ }^{37}$ Ibn Sa'd, al-Tabaqat Kubra, Jilid I, h. 220. dalam Majid Ali Khan, Majid Ali Khan, Muhammad The Final Massenger diterjemahkan oleh Fathul Umam dengan judul Muhammad saw. Rasul Terakhir, h. 81. 
mengajarkan Islam. ${ }^{38}$ Setelah beberapa hari berada di Yastrib ia berhasil mengislamkan dua orang terkemuka yaitu Sa'd bin Mu'az dan Usaid bin Hudair. ${ }^{39}$ Dengan maksud kedua orang terkemuka itu, ia berhasil mengislamkan seluruh anggota suku Asyhal. Kematangan rencana itu, dibuktikan oleh muballig utusan Nabi ke Yastrib dengan datangnya orang-orang Yastrib ke Mekkah sebanyak 73 orang laki-laki dan dua orang perempuan untuk bertemu dengan $\mathrm{Nabi}^{40}$ Yang berintikan tentang persepakatan kedua belah pihak untuk saling melindungi dan membela kepentingan bersama.

Langkah yang ditempuh Rasulullah saw. di atas, membuahkan hasil yang gemilang, dengan semakin meningkatnya jumlah pemeluk dan pembela Islam di Yastrib, ${ }^{41}$ mereka semakin besar pula peluang untuk berhijrah. Setelah Rasulullah tiba di Yastrib, maka langkah pertama yang dilakukan mendirikan masjid, sebagai pusat ibadah dan tempat pertemuan umat Islam. ${ }^{42}$

Dengan adanya masjid tersebut menjadi suatu mata rantai dari rencana panjang Rasulullah dalam mempersatukan umat dalam suatu wadah yang multi guna. Karena di masjid inilah Rasulullah menciptakan suasana damai, kabilahkabilah yang asalnya jauh, kini menjadi dekat dan perpecahan menjadi persatuan, dan di tempat ini pula membuat rencana-rencana selanjutnya bahkan pembinaan umat dan pengembangan ilmu pengetahuan. Setelah beliau berhasil mendirikan masjid, maka langkah rencana selanjutnya adalah mempersatukan kaum muslim, antara Muhajirin dan Anshar, mereka dipersatukan atas dasar senasib sepenanggungan, bukan atas dasar hubungan darah. ${ }^{43}$

Setelah Rasulullah berhasil mempersaudarakan kaum Muhajirin dan Anshar, maka salah satu rencana yang cukup spektakuler adalah membuat

\footnotetext{
${ }^{38}$ Ibn Hisyam dan Phillip K.Hitti, The Arabs a Short History diterjemahkan oleh Ushuluddin Hutagalung dan ODP Sihombing dengan judul Dunia Arab Sejarah Singkat (Bandung: Sumur, t.th), h. 434. Lihat juga Sa'id bin Ali al-Qaththani, al-Hikmatu fi al-Dakwah ila Allah Ta'ala diterjemahkan oleh Masykur Hakim dan Ubaidillah dengan judul Dakwah Islam Dakwah Bijak, h. 121.

${ }^{39}$ Thomas W. Arnold, The Preaching of Islam diterjemahkan oleh H.A. Nawawi Rambe dengn judul Sejarah Dakwah Islam (Jakarta: Wijaya, 1981), h. 20.

${ }^{40}$ Sa'id bin Ali al-Qaththani, al-Hikmatu fi al-Dakwah ila Allah Ta'ala diterjemahkan oleh Masykur Hakim dan Ubaidillah dengan judul Dakwah Islam Dakwah Bijak, h. 121. Mengenai jumlah penduduk Yastrib yang datang, terdapat perbedaan. Ahmad Syalabiy, Sejarah dan Kebudayaan Islam, Jilid I (Jakarta: Pustaka al-Husna, 1983), h. 106.

${ }^{41}$ Muhammad Syafrullah dalam J. Suyuthi Pulungan, Prinsip-Prinsip Pemerintahan dalam Piagam Madinah Ditinjau dari Pandangan Alquran, h. 55.

${ }^{42}$ Sa'id bin Ali al-Qaththani, al-Hikmatu fi al-Dakwah ila Allah Ta'ala diterjemahkan oleh Masykur Hakim dan Ubaidillah dengan judul Dakwah Islam Dakwah Bijak., h. 123.

${ }^{43}$ Sa'id bin Ali al-Qaththani, al-Hikmatu fi al-Dakwah ila Allah Ta'ala diterjemahkan oleh Masykur Hakim dan Ubaidillah dengan judul Dakwah Islam Dakwah Bijak., h. 125-126.
} 
perjanjian antara kaum Muslimin dan Yahudi. ${ }^{44}$ Perjanjian 'Aqabah I dan II, mendirikan masjid, mempersaudarakan Muhajirin dan Anshar, serta membuat perjanjian antara umat Islam dengan Yahudi, merupakan urutan program yang sangat rapi, sehingga hanya dalam waktu satu dasawarsa, rencana besar itu dapat diwujudkan dengan sempurna.

\section{Strategi Pengorganisasian Dakwah Rasulullah}

Organizing merupakan tindakan penyatuan yang terpadu, utuh dan kuat dalam suatu wadah organisasi. Rasulullah saw. di dalam memanfaatkan pengorganisasian dakwah guna mencapai suatu tujuan ${ }^{45}$ maka beliau menempuh beberapa tahapan. Rasulullah saw. di dalam menjalankan proyek raksasanya yaitu mewujudkan masyarakat madani, maka beliau mengelompokkannya ke dalam tiga tahapan besar yaitu:

1. Tahap Pembentukan

Pada tahap ini beliau melaksanakan dakwah bi al-lisan (tabligh) sebagai ikhtiar sosialisasi ajaran tauhid kepada masyarakat Mekkah, kegiatan ini dilakukan secara bertahap, dan secara sembunyi-sembunyi. ${ }^{46}$

Rasulullah saw. memulai dakwahnya secara sembunyi-sembunyi melalui orang-orang terdekat, yaitu isteri beliau sendiri, Khadijah binti Khaulid, maka masuklah Ali bin Abi Thalib dan Zaid bin Haritsah dan Abu Bakar. ${ }^{47}$ Sasarannya adalah supaya terjadi internalisasi Islam dalam kepribadian yang lemah, dan sesudah diterima dan dicerna dapat diekspresikan dalam kegairahan dan sikap membela keimanan (akidah) dari tekanan struktur al-mala (pemuka masyarakat) dan kaum al-mutrafin (pedagang kayu) Quraisy Mekkah. Hasilnya adalah para elit politik, elit ekonomi, tokoh masyarakat dan massa masyarakat menerima dengan baik dakwah Rasulullah saw.

Tekanan struktural al-mala pemuka Quraisy semakin keras terhadap dakwah Nabi, para pengikut dan penopang dakwah banyak yang mengalami siksaan, untuk itu Nabi menyarankan hijrah ke Habsyah ${ }^{48}$ dan diikuti pemindahan sasaran dakwah Nabi ke Thaif, ${ }^{49}$ walaupun pada akhirnya memperoleh kegagalan.

\footnotetext{
${ }^{44}$ Majid Ali Khan, Muhammad The Final Massenger diterjemahkan oleh Fathul Umam dengan judul Muhammad saw. Rasul Terakhir, h. 94.

${ }^{45}$ Wardi Bachtiar, Metodelogi Penelitian Ilmu Dakwah (Jakarta: Logos, 1997), h. 37.

${ }^{46}$ Abdurrahman al-Baghdady, Dakwah Islam dan Masa Depan Umat (Bangil: al-Izzah, 1997), h. 35.

${ }^{47}$ Sa'id bin Ali al-Qaththani, al-Hikmatu fi al-Dakwah ila Allah Ta'ala diterjemahkan oleh Masykur Hakim dan Ubaidillah dengan judul Dakwah Islam Dakwah Bijak, h. 108.

${ }^{48}$ Sa'id bin Ali al-Qaththani, al-Hikmatu fi al-Dakwah ila Allah Ta'ala diterjemahkan oleh Masykur Hakim dan Ubaidillah dengan judul Dakwah Islam Dakwah Bijak., h. 62.

${ }^{49}$ Sa'id bin Ali al-Qaththani, al-Hikmatu fi al-Dakwah ila Allah Ta'ala diterjemahkan oleh Masykur Hakim dan Ubaidillah dengan judul Dakwah Islam Dakwah Bijak, h. 65.
} 
Pertemuan Nabi dengan kabilah yang datang dari Yastrib mengungkapkan dua hal penting. Pertama, Islam dapat diserap di luar kota Mekkah. Kedua, Nabi mengerti karakteristik tata sosial Yastrib dengan seperangkat permasalahannya. Dengan demikian, Nabi memahami tingkat konfliknya tinggi dan rendah tingkat integritasnya, yang memerlukan figur pemimpin dalam kerangka ideologis pemersatu. Oleh karena itu, Nabi melihat format demikian, lalu menjembataninya dengan tauhid dan sosiologis. Jembatan itu menghasilkan perjanjian 'Aqabah I dan II.

Tahapan pertama di atas merupakan tahapan ideologis, sebagai upaya dakwah dalam mengemban dan menetapkan fondasi kehidupan dalam sebuah struktur masyarakat yang kuat. ${ }^{50}$

2. Tahap Penataan dan Pengembangan Dakwah

Pada pengelompokan kerja kedua ini, merupakan tahapan konsepsional yang merupakan pembangunan struktur masyarakat, sehingga menjadi sebuah masyarakat yang dapat mentransformasikan nilai-nilai dan konsep-konsep Islam yang berlandaskan tauhid ke seluruh dimensi kehidupan. ${ }^{51}$ Tahap penataan ini merupakan realisasi dari hijrah yang dilaksanakan setelah Nabi memahami karakteristik sosial Madinah baik melalui informasi Mus'ab bin Umair maupun interaksi Nabi dengan jama'ah peserta bai'ah 'Aqabah.

Nabi mengawali pengelompokan kerjanya yang kedua pada penataan dan pengembangan dakwah dengan hijrah. Setelah Nabi memperoleh izin hijrah (QS. 22 : 39) dan setelah sampai di Madinah, maka Nabi mencanangkan beberapa langkah yang mendasar dan menjadi tonggak sejarah perjuangan beliau adalah:

a. Mendirikan masjid Quba dan masjid Nabawi di Madinah. ${ }^{52}$

b. Membentuk lembaga ukhuwah Islamiyah antara Muhajirin dan Anshar. ${ }^{53}$

c. Membuat perjanjian antara kaum Muslimin dengan kaum Yahudi yang dikenal dengan "Piagam Madinah". 54

3. Tahap Pembinaan

Tahapan ini disebut juga dengan tahapan operasional yang berarti mensosialisasikan seluruh konsep Islam dalam alam kenyataan dan membuktikan

${ }^{50}$ Adi Sasono, et. all., Solusi Islam atas Problematika Umat: Ekonomi, Pendidikan, dan Dakwah, h. 208.

${ }^{51}$ Adi Sasono, et. all., Solusi Islam atas Problematika Umat: Ekonomi, Pendidikan, dan Dakwah, h. 208

${ }^{52}$ Ahmad Ibrahim Syarif, Daulat al-Rasail fi al-Madinat (Kuwait: Dar al-Bayan, 1979), h. 87.

${ }^{53}$ Abdul Hamid Judah al-Sahhar, Sirah Rasulullah Periode Madinah, edisi Terjemah (Bandung: Mizan, 1994), h. 16.

${ }^{54}$ J. Suyuthi Pulungan, Prinsip-prinsip Pemerintahan dalam Piagam Madinah Ditinjau dari Pandangan Alquran, h. 64. 
keunggulannya di hadapan konsepsi-konsepsi yang batil sehingga tidak ada lagi fitnah dan agama hanya untuk Allah. ${ }^{55}$

\section{Strategi Penggerakan Dakwah Rasulullah}

Penggerakan dakwah yang telah dilakukan Rasulullah saw. baik dalam lingkungan intern umat Islam maupun di luar umat Islam, namun satu dalam negara. Rasulullah saw. di dalam menunjukkan kemampuannya menyadarkan orang lain dalam rangka bela negara, beliau telah berhasil mempengaruhi Bani Dhamrah (saat itu belum Islam), untuk bersama-sama mempertahankan negara dari serangan musuh. ${ }^{56}$

Perang yang dilakukan Rasulullah saw. bukanlah dalam rangka dakwah, tetapi perang adalah rangka membela dakwah. Dalam berbagai fakta sejarah menunjukkan bahwa umat Islam tidak pernah memerangi suatu kaum sebelum dakwah sampai kepadanya, dan tidak menghina umat Islam.

Pada tahun kedua hijriah, orang Quraisy mulai menyulut api peperangan dengan memprovokasi Abdullah bin Ubaiy. ${ }^{57}$ Dengan menulis surat yang berbunyi: "Untuk memberi suaka kepada orang-orang kami, maka kami mohon saudara atas nama Tuhan agar membunuhnya atau mengusirnya dari Madinah (bila saudara tidak menuruti) kami akan menyerang saudara, menghancurkan saudara dan kami akan menawan kaum wanita saudara."58 Namun surat itu tercium oleh Rasulullah saw. lalu beliau menemui Abdullah bin Ubaiy, akhirnya peperangan tak terelakkan.

Walaupun demikian, kaum Quraisy tidak berhenti melawan orang Islam. Bahkan setelah peristiwa di atas, kaum muslimin menghadapi tiga aliansi musuh yaitu: Quraisy, Yahudi dan Munafiq yang dipimpin oleh Abdullah bin Ubaiy. ${ }^{59}$

Untuk menyadarkan umat Islam dan orang-orang yang tinggal di sekitar Madinah, dan dalam rangka penggerakan dakwah, maka beliau membuat fakta perdamaian dengan Bani Dhamrah. Isi perjanjian itu adalah: "Ini adalah perjanjian Muhammad dengan Bani Dhamrah. Kehidupan mereka dan hak milik mereka akan selamat, bila ada musuh datang menyerang mereka, maka mereka akan mendapat bantuan dari kaum muslimin, selama bukan perang agama. Mereka juga

\footnotetext{
${ }^{55}$ Adi Sasono, et. all., Solusi Islam atas Problematika Umat: Ekonomi, Pendidikan, dan Dakwah., h. 209.

${ }^{56}$ Majid Ali Khan, Muhammad The Final Massenger diterjemahkan oleh Fathul Umam dengan judul Muhammad saw. Rasul Terakhir, h. 102.

${ }^{57}$ Sa'id bin Ali al-Qaththani, al-Hikmatu fi al-Dakwah ila Allah Ta'ala diterjemahkan oleh Masykur Hakim dan Ubaidillah dengan judul Dakwah Islam Dakwah Bijak h. 155-156.

${ }^{58}$ Syibli Nu'mani, Siratun Nabi, Jilid I, h. 305.

${ }^{59}$ Syibli Nu'mani, Siratun Nabi, h. 101.
} 
harus membantu Nabi bila diperlukan." 60

Memperhatikan isi perjanjian di atas, maka Rasulullah patut dipuji kemampuannya untuk menggerakkan orang lain (non muslim) untuk mengangkat senjata dan bantuan lain bila diperlukan. Keunikannya adalah kesediaan kerjasama orang-orang yang pada dasarnya memusuhi Nabi, namun pada kesempatan yang tepat beliau mampu menggalangnya untuk bekerjasama dengan penuh sukarela, namun atas dasar bela negara.

\section{Strategi Pengendalian dan Evaluasi Dakwah Rasulullah}

Menurut al-Ghazali sebagaimana dikutip oleh Didin Hafidhuddin menyebutkan bahwa proses dakwah yang bermula dari dasar asumsi yang berorientasi pada sistem sosial dapat diperinci menjadi tiga tahap yaitu: menyadarkan pikiran, menumbuhkan keyakinan dan membangun sistem. ${ }^{61}$

Upaya pengendalian dan evaluasi dakwah Rasulullah saw. terdapat pada tugas yang dilakukan Muz'ab bin Umair sebagai tugas intelijen dan tugas muballig ke Yastrib menyusul perjanjian 'Aqabah yang I.

Setelah Muz'ab bin Umair melaksanakan tugasnya di Yastrib, lalu Nabi mengevaluasi dengan melihat langsung dari hasil kerjanya yaitu dengan bersedianya 73 orang yang berseteru mengadakan perjanjian dengan Nabi yang dikenal dengan perjanjian 'Aqabah II. ${ }^{62}$

Begitu pentingnya pengendalian dan evaluasi yang diadakan Rasulullah saw. di 'Aqabah, karena hal itu menjadi tonggak sejarah hijrahnya Nabi. Kalau saja Rasulullah saw. tidak menghiraukan perlunya evaluasi, maka hijrah pun sulit dilakukan, sebab survey yang dilakukan oleh Muz'ab bin Umair sangat menentukan masa depan Islam. Pada peristiwa fathul Mekkah, dengan kekuatan pasukan yang besar. Untuk menghindari kemungkinan adanya penyimpangan, maka Nabi membagi empat kelompok pasukan. Pada saat itu Nabi memberikan garis kebijaksanaan yaitu "bahwa masing-masing tidak boleh mempergunakan kekuatan senjata atau melakukan kekerasan yang menimbulkan pertumpahan darah, kecuali jika memang sangat terpaksa.

Dari sini pula dapat dilihat bahwa dari berbagai kebijakan yang

\footnotetext{
${ }^{60}$ Muhammad the Final Massenger diterjemahkan oleh Fathul Umam dengan judul Muhammad saw. Rasul Terakhir, h. 102-103.

${ }^{61}$ Adi Sasono, et all., Solusi Islam atas Problematika Umat (Ekonomi, Pendidikan dan Dakwah), h. 192-193

${ }^{62}$ Sa'id bin Ali al-Qaththani, al-Hikmatu fi al-Dakwah ila Allah Ta'ala diterjemahkan oleh Masykur Hakim dan Ubaidillah dengan judul Dakwah Islam Dakwah Bijak, h. 182-184. Lihat juga Muhammad Yusuf al-Kandhalawiy, Hadisus Sahabah diterjemahkan oleh Bey Arifin dan Yunus Ali al-Muhdar dengan judul Kehidupan Para Sahabat Rasulullah saw. Surabaya: Bina Ilmu, 1982), h. 180-182.
} 
dilaksnakan Rasulullah saw. sangat sesuai dengan fungsi-fungsi manajemen dakwah yang disesuaikan dengan semangat manajemen pada umumnya.

\section{SIMPULAN}

Dari kajian yang komprehensif dan analisis terhadap strategi dakwah Rasulullah dalam lintas sejarah Islam, maka ditemukan beberapa langkah-langkah strategi dakwah. Di samping itu ditemukan adanya relevansi atau kesesuaian antara ilmu manajemen (yang dikembangkan pada abad modern) dengan manajemen dakwah yang dipraktekkan Rasulullah saw. baik di Mekkah (sebelum hijrah) maupun di Madinah.

Strategi perencanaan dakwah Rasul diawali di Mekkah dengan mengunjungi orang Yastrib yang datang di Mekkah untuk melaksanakan haji, yang selanjutnya diikuti dengan perjanjian 'Aqabah I dan II dengan mengutus Mus'ab bin Umair ke Yastrib untuk mempelajari situasi sekaligus mengajarkan Islam. Selanjutnya, setelah Rasulullah tiba di Madinah, beliau mendirikan masjid dan mempersaudarakan umat Islam. Segi perencanaan dakwah dari peristiwa (mendirikan masjid dan mempersaudarakan) terletak pada kondisi sosial, ekonomi dan budaya khususnya kaum Muhajirin yang datang di Madinah tanpa bekal.

Strategi pengorganisasian dakwah Rasul dilakukan dengan melalui beberapa tahapan yaitu: 1) Tahap pembentukan, yang diawali dengan dakwah secara sembunyi-sembunyi melalui orang-orang terdekat, dan dakwah terbuka setelah adanya dukungan dari beberapa orang pembesar Quraisy. 2) Tahap penataan dan pengembangan dakwah, yang diawali pada pelaksanaan hijrah ke Madinah dengan mendirikan Masjid, membentuk lembaga ukhuwah dan membuat perjanjian antara kaum muslimin dan kaum Yahudi. 3) Tahap pembinaan, melaui keluarga, suri tauladan, pembinaan terhadap prinsip keadilan sosial.

Strategi penggerakan dakwah Rasulullah, intinya adalah suatu upaya menyadarkan umat Islam dan non-Islam untuk bekerjasama antara satu dengan yang lainnya dalam rangka mencapai tujuan bersama. Motivasinya adalah melalui iman dan amal saleh, bela agama Allah dan musyawarah.

Strategi pengendalian dan evaluasi dakwah dimaksudkan untuk mengetahui sejauhmana tugas-tugas dakwah telah dilaksanakan, bagaimana pelaksanaannya, bagaimana melaksanakan dan penyimpangannya. Hal tersebut Rasulullah telah melaksanakannya pada diri Mus'ab bin Umair ketika ia diutus oleh Nabi ke Yastrib.

\section{DAFTAR PUSTAKA}

Abdul Hamid Judah al-Sahhar, Sirah Rasulullah Periode Madinah, edisi Terjemah, Bandung: Mizan, 1994. 
Abdurrahman al-Bagdadiy, Dakwah Islam dan Masa Depan Umat, Bangil: alIzzah, 1997.

Abi Muhammad Abdul Malik bin Hisyam, Sirah al-Nabawiy, Jilid II (Beirut: Dar al-Fikr, t.th.

Abi Sujak, Kepemimpinan Manajer: Eksistensi dalam Perilaku Organisasi, Jakarta: Rajawali, 1990.

Abu 'Abdullah Ahmad bin Hanbal, Musnad Ahmad bin Hanbal, Jilid V, Beirut: alMaktab al-Islamy, 1978.

Adi Sasono, et all., Solusi Islam atas Problematika Umat (Ekonomi, Pendidikan dan Dakwah), Jakarta: Gema Insani Press, 1998.

Ahmad Ibrahim Syarif, Daulat al-Rasail fi al-Madinat, Kuwait: Dar al-Bayan, 1979.

Dedy Susanto. Psikoterapi Religius Sebagai Strategi Dakwah Dalam Menanggulangi Tindak Sosiopatic (Studi di Pondok Pesantren Istighfar Semarang). Konseling Religi: Jurnal Bimbingan Konseling Islam, 2013.

Fremont E. Kast dan James E. Rosenzwing, Organizing and Management. Diterjemahkan oleh A. Hasjmi Ali dengan judul Organisasi dan Manajemen Jilid I, Jakarta: Bumi Aksara, 1995.

Hamka Haq, Filsafat Ushul Fiqh (Ujungpandang: Yayasan Al-Ahkam, 1998.

Hasan Basri. Manajemen Dakwah Nabi saw di Madinah. Al-Munzir, 2015, 8 (2), 179-196.

Hayat. Strategi Dakwah NU Dalam Membangun Mental Dan Karakter Masyarakat Walisongo. Jurnal Walisongo. 2014.

Husayn Ahmad Amin, al-Mi'ah al-Azam fi tarikh al-Islam, Bandung: Remaja Rosdakarya, 1999.

Ibn Hisyam dan Phillip K.Hitti, The Arabs a Short History diterjemahkan oleh Ushuluddin Hutagalung dan ODP Sihombing dengan judul Dunia Arab Sejarah Singkat (Bandung: Sumur, t.th.

Ibn Hisyam dan Phillip K.Hitti, The Arabs a Short History diterjemahkan oleh Ushuluddin Hutagalung dan ODP Sihombing dengan judul Dunia Arab Sejarah Singkat, Bandung: Sumur, t.th.

Imam Hafidz Abi Ali Muhammad bin Abdul Rahman bin Abd. Rahim al-Mabari al-Kufra, Tuhfatu al-Ahwaz bi Syarhi Jami' al-Turmuzy, Jilid IV, Dar al- 
Fikr, 1979.

J. Suyuthi Pulungan, Prinsip-prinsip Pemerintah dalam Piagam Madinah: Ditinjau dari Pandangan Alquran, Jakarta: Raja Grafindo Persada, 1996.

Khalid Ibrahim Malla Khathir, Fadhail al-Madinah al-Munawwarah, Jilid I, Madinah: Maktabah Dar al-Turats, 1993.

M. Fu'ad Hashem, Sirah Muhammad Rasulullah: Suatu Penafsiran Baru, Bandung: Mizan, 1989.

Madjid Ali Khan, Muhammad the Final Massenger diterjemahkan oleh Fathul Umam dengan judul Muhammad saw. Rasul Terakhir, Bandung: Pustaka, 1985.

Michael H. Hart, Seratus Tokoh yang Paling Berpengaruh dalam Sejarah, Jakarta: Pustaka Jaya, 1983.

Mudjiono, Y. Strategi dakwah wali songo dalam perspektif ilmu komunikasi. Jurnal Ilmu Dakwah Vol. 14 No. 1 April 2007.

Muhammad Athiliyahal-Abrasyiy, Adhamatur Rasul diterjemahkan oleh Muhammad Tohir dan Abulailah dengan judul Keagungan Muhammad Rasulullah saw, Bandung: Dunia Pustaka Jaya, 1985.

Muhammad Ali RS, S. (2009). STRATEGI DAN ETIKA DAKWAH RASULULLAH SAW. Ilmu Dakwah.

S.Ag., ME, H. (2017). Strategi dan Metode Dakwah Walisongo. Al-Hiwar : Jurnal Ilmu dan Teknik Dakwah, 3(5). https://doi.org/10.18592/alhiwar.v3i5.1193

Muhammad Yusuf al-Kandhalawiy, Hadisus Sahabah diterjemahkan oleh Bey Arifin dan Yunus Ali al-Muhdar dengan judul Kehidupan Para Sahabat Rasulullah saw. Surabaya: Bina Ilmu, 1982.

Nourouzzaman Shiddiq, Jeram-jeram Peradaban Muslim, Yogyakarta: Pustaka Pelajar, 1996.

Onong Uchjana Effendi, Kepemimpinan dan Komunikasi, Bandung: Mandar Maju, 1992.

Sa'id bin Ali al-Qaththani, al-Hikmatu fi al-Dakwah ila Allah Ta'ala diterjemahkan oleh Masykur Hakim dan Ubaidillah dengan judul Dakwah Islam Dakwah Bijak (Jakarta: Gema Insani Press, 1994.

Syaikh Abdurrahman Abdul Khaliq, Fus-lun min Nasiyasati Syar'iyati fi Dakwah Ilal Allah, diterjemahkan oleh Marsuni Sosaky dan Mustahab Hasbullah, 
dengan judul Metode dan Strategi Dakwah Islam (Jakarta: Pustaka alKausar, 1996.

Syibli Nu'mani, Siratun Nabi, Jilid I.

Thomas W. Arnold, The Preaching of Islam diterjemahkan oleh A. Nawawi Rambe dengan judul Sejarah Dakwah Islam, Jakarta: Widjaya, 1981.

Tim Penyusun Teks Book Sejarah Kebudayaan Islam Dirjen Bimbingan Islam, Sejarah dan Kebudayaan Islam, Jilid I, Ujungpandang: Proyek Pembinaan Perguruan Tinggi Agama IAIN Alauddin, 1981-1982.

Wardi Bachtiar, Metodelogi Penelitian Ilmu Dakwah, Jakarta: Logos, 1997.

William E. Phipps, Muhammad and Jesus: A Comparison of The Prophets and Their Techings, diterjemahkan oleh Ilyas Hasan dengan judul Muhammad dan Isa: Sebuah Telaah Kritis atas Risalah dan Tokohnya, Bandung: Mizan, 1998. 